ROCZNIKI NAUK SPOŁECZNYCH

Tom 12(48), numer $1-2020$

DOI: https://doi.org/10.18290/rns20481-2

WITOLD JEDYNAK

\title{
THE LEADER'S ROLE \\ IN BUILDING RELIGIOUS SOCIAL CAPITAL: A RELIGIOUS REGIONAL COMMUNITY LEADER IN POLAND
}

\section{INTRODUCTION}

Out of all the former Soviet Bloc countries in Central-Eastern Europe, Poland is seen as the democratic process change leader. It was the first to bring about a regime change without bloodshed. Certain members of the Catholic Church clergy played significant roles in the social and political transformation taking Poland from an authoritarian system towards democracy and a civil society. Ignacy Tokarczuk (1918-2012), a Polish Bishop and Przemyśl diocesan belongs to that group. He is highly recognisable in Podkarpackie Province, spanning the South-Eastern fringes of Poland. ${ }^{1}$

Tokarczuk was active as the Bishop of Przemyśl (1966-1993) during the Polish People's Republic era and at the start of the political transformation. This was a difficult time for the Catholic Church, as the communist authorities, following instructions from Moscow, were aiming for an atheisation of the society and attempted to remove religion from the public life. Tokarczuk was able to awaken religious social capital within local parish communities and despite numerous adversities, achieved dynamic growth in the Przemyśl Diocese which he oversaw. His strategy aimed at integrating Catholics living within the diocese proved to be effective as it "awoke a giant" in the form of lay worshipers in the Church. It made it possible to counteract the repressive beliefs policy imposed by the

WitOLD JEDYNAK PhD-Institute of Sociological Science University of Rzeszów; address for correspondence: Al. Rejtana 16 C, 35-959 Rzeszów; e-mail: vox321@interia.pl; ORCID: https://orcid.org/0000-0002-7101-8537.

${ }^{1}$ K. MALICKI, Polacy i ich pamięć przeszłości. Studium socjologiczne pamięci zbiorowej na przykładzie regionu podkarpackiego (Kraków: Zakład Wydawniczy Nomos, 2012), 88-9. 
communist authorities. ${ }^{2}$ The widespread involvement of the population of Podkarpacie in the Catholic Church has become a strong determinant in increasing the level of social capital. ${ }^{3}$

Tokarczuk's actions did not only effectively stifle anti-religious efforts undertaken by the communists, which sought to bring about disintegration and a weakening of religious communities in the Diocese of Przemyśl, but also paved the way for social and religious lives of the Podkarpackie community to thrive. The bishop inspired Podkarpackie residents to build a civil society whose members are actively engaged and aware of community issues-in taking responsibility for the common good, together they sought to satisfy collective needs. The hierarch paid particular attention to bottom-up social initiatives as he was convinced that citizens know best what their needs are and are able to organise themselves in order to satisfy them. ${ }^{4}$

Tokarczuk's pastoral work clearly contributed to the building of social capital, which comprises everything necessary for common action for the common good across various social life disciplines. The most important components of social capital include: shared responsibility for the common good, shared understanding, desire to cooperate for the common good, establishing groups, mutual trust, a system of shared standards and values and interpersonal relationships. ${ }^{5}$

Religious social capital is a type of social capital. Social capital assumes a religious form, when its sources and manifestations are associated with religion. In other words, religious social capital is built on the basis of religious resources. It represents bonds amongst fellow worshipers, social commitment in the form of belonging and pro-community efforts, an interpersonal network between community members, observance of values and moral standards inherent to a religion,

\footnotetext{
${ }^{2}$ K. BEŁCH, "Strategie duszpasterskie arcybiskupa Ignacego Tokarczuka," in Arcybiskup Ignacy Tokarczuk w oczach spoteczeństwa, ed. J. Zimny (Sandomierz: Wydawnictwo Diecezjalne, 2003), 218-20; I. TOKARCZUK, "Integracyjna rola diecezji przemyskiej w Małopolsce po ostatniej wojnie," in S. Czerwik, and M. Mierzwa, Diligis me? Pasce, vol. 1, (Sandomierz: Wydawnictwo Diecezjalne, 1999), 766-80.

${ }^{3}$ See M. AleXANDER, "Determinants of Social Capital: New Evidence on Religion, Diversity and Structural Change," British Journal of Political Science 37, no 2 (2007), 368-77.

${ }^{4}$ E. Frankowski, "Homilia," in Pożegnanie "Niezłomnego Pasterza" Arcybiskupa Ignacego Tokarczuka, ed. J. Łoboz (Przemyśl: Wydawnictwo i Drukarnia Diecezji Rzeszowskiej, 2013), 12-3.

${ }^{5}$ F. FukUYama, Zaufanie. Kapitat spoteczny a droga do dobrobytu, trans. A. and L. Śliwa (Warszawa-Wrocław: Wydawnictwo Naukowe PWN, 1997), 38; R.D. Putnam, Samotna gra w kręgle. Upadek i odrodzenie wspólnot lokalnych w Stanach Zjednoczonych (Warszawa: Wydawnictwa Akademickie i Profesjonalne, 2008), 33; K. SIEROCIŃSKA, "Kapitał społeczny. Definiowanie, pomiar i typy," Studia Ekonomiczne, no. 1 (2011): 71-2.
} 
religious practices. Religious social capital impacts the group within which it occurs as well as the wider community. ${ }^{6}$

A charismatic leader plays an important role in awakening religious social capital. Bishop Tokarczuk was an undisputed leader for Catholics in the Diocese of Przemyśl. That's why the author made an attempt at depicting the role which its diocesan played in building religious social capital in the Diocese of Przemyśl. The most important dimensions of religious social capital generated by the bishop are identified. As social phenomena from the past constitute the subject-matter of the research, a method constituting an analysis of available sources was employed. The author of the article analysed selected texts by Bishop I. Tokarczuk wherein the latter outlined the process of "awakening" social capital. Furthermore, the scientific enquiries encompassed published scientific articles, memoirs, reports, interviews of other individuals broaching the subject of Bishop of Przemyśl's pastoral work.

\section{SHARED RESPONSIBILITY FOR RELIGIOUS COMMUNITIES}

One of the primary tasks which Tokarczuk tried to complete was to awaken shared responsibility for the common good amongst worshippers, a subjectification of Catholics who are to become active participants of religious and community lives. Shared responsibility manifests itself in the willingness to influence the functioning of a local parish community and is a manifestation of religious social capital. ${ }^{7}$ Building social capital brings the following benefits: atmosphere conducive for working together, frequent interpersonal contacts, belonging, powerful and lasting social identity, cooperation, bottom-up mobilisation, effectiveness, innovation. ${ }^{8}$

Awakening responsibility in lay people for local parish community matters which Tokarczuk undertook was a difficult task due to age-old stereotypes and practical experiences, according to which priests in the Catholic Church were responsible for religious matters whereas lay people were usually passive

\footnotetext{
${ }^{6}$ W. SADŁoŃ, “'Bardziej ubogo, ale przyzwoiciej.' Oddziaływanie religijnego kapitału społecznego w Polsce," Zeszyty Naukowe KUL 57, no. 1 (2014): 15-7; W. SADŁoń, Religijny kapitat spoteczny. Kapitat spoteczny a Kościót katolicki w spotecznościach lokalnych w Polsce (Wydawnictwo Bezkresy Wiedzy, 2014), 33-4, 262, accessed November, 2018, https://www.researchgate.net/publica tion/303523181_Religijny_kapital_spoleczny.

${ }^{7}$ P. SzTOMPKA, Kapitat spoteczny. Teoria przestrzeni międzyludzkiej (Kraków: Wydawnictwo Znak, 2016), 255-6.

${ }^{8}$ SzTOMPKA, Kapitat spoteczny, 309.
} 
participants of religious gatherings. ${ }^{9}$ Additionally the social and political conditions made subjectification of lay people in the Polish People's Republic difficult. The ruling party not only restricted, but also effectively blocked individual, bottom-up initiatives as well as creative and entrepreneurial efforts by citizens across various social life dimensions. ${ }^{10}$ By introducing political and administrative control over the activities of organisations operating in the Polish People's Republic, the authorities discouraged the citizens from participating in public activities. ${ }^{11}$ The communist policy aimed at centralising all manifestations of social life, resulting in weak social and moral bonds, lack of structure on intermediate levels between the family and the state. ${ }^{12}$

Tokarczuk wanted to activate lay Catholics and organise them into informal groups. However, first he was forced to identify theoretic and doctrinal foundations for his pastoral strategy. ${ }^{13} \mathrm{He}$ found these in the traditions of the first Christians ${ }^{14}$ and in the resolutions of the Vatican Council wherein the role of lay Catholics in the mission of the Church was emphasised. ${ }^{15}$

Tokarczuk argued publicly that everyone-both the clergy and the lay-are needed and are indispensable to the Church as they all have important roles to play therein. Their social roles are mutually complimentary and supportive. Failure to unlock the vast potential in laity would constitute a tremendous loss

${ }^{9}$ I. TOKARCZUK, "Śladami Vaticanum II. Rozmowa z ojcem synodalnym [...]. Rozmawiała siostra J. Makowicz," Niedziela 30, no. 47 (1987), 4; E. WERON, Apostolstwo katolickie. Zarys teologii apostolstwa (Poznań: Pallottinum, 1987), 136-7; E. WERON, Budzenie olbrzyma. Laikat - duchowość - apostolstwo. Akcja Katolicka (Poznań: Pallottinum, 1995), 22-3.

${ }^{10}$ M. TARniewski [Karpiński J.], Ewolucja czy rewolucja (Paryż: Instytut Literacki, 1975), 111-2; H. ŚwIDA-ZIEMBA, Cztowiek wewnętrznie zniewolony. Mechanizmy i konsekwencje minionej formacji - analiza psychospoteczna (Warsaw: Zakład Socjologii Moralności i Aksjologii Ogólnej Instytut Stosowanych Nauk Społecznych, Uniwersytet Warszawski, 1997), 80-1, 308-9.

${ }^{11}$ M. ADAMCZYK, "Kapitał społeczny szansą na budowanie partnerskich relacji we wspólnotach lokalnych," in Pomoc jako zachowanie prospoteczne, ed. T. Zbyrad, and B. Krempa (Lublin: Wydawnictwo KUL, 2012), 489-90.

${ }^{12}$ F. FUKUYAMA, Zaufanie, 69-70; M. ADAMCZYK, Wprowadzenia do teorii kapitatu spotecznego (Lublin: Wydawnictwo KUL, 2013), 73-4.

${ }^{13}$ I. TOKARCZUK. Z przemyskiej “twierdzy,” part 1, comp. by L. Żbikowska (Marki: Michalineum, 1999), 66; T. SzCZUREK, "Konsekracja oraz ingres do bazyliki katedralnej w Przemyślu J.E. Ks. Biskupa Ignacego Tokarczuka," Kronika Diecezji Przemyskiej 52, f. 2 (1966), 44.

${ }^{14}$ I. ToKARCZUK, "Cywilizacja miłości," Nasza Rodzina no. 5 (1986), 24-31; I. ToKARCZUK, "O świeckich w Kościele w przeddzień synodu. Wywiad z biskupem przemyskim [...]. Rozmawiał F. Szpor,” Gość Niedzielny 64, no. 39 (1987), 4.

${ }^{15}$ SOBÓR WATYKAŃSKI II, "Dekret o apostolstwie świeckich “Apostolicam actuositatem,'” in Konstytucje, dekrety, deklaracje, $3^{\text {rd }}$ ed. (Poznań: Wydawnictwo Pallottinum, 1986), 388-9; Sobór Watykański II, "Konstytucja duszpasterska o Kościele w świecie współczesnym 'Gaudium et spes,"” in Konstytucje, dekrety, deklaracje, $3^{\text {rd }}$ ed. (Poznań: Wydawnictwo Pallottinum, 1986), 570-1. 
of the Church. ${ }^{16}$ In the bishop's opinion, cooperation between the clergy and laity was to strengthen social bonds in church communities and improve the trust between priests and lay people. ${ }^{17}$ Trust became the basic strategy for dealing with uncertain, unknown future behaviour of individuals. ${ }^{18}$

Tokarczuk knew that if he managed to convince worshippers that participation in a local religious community required their personal engagement, then the contribution of lay people to the development of the local Church will increase. Strengthening shared responsibility for a religious community will result in increased interest in parish matters and an increase to the level of commitment by Catholics to the common good of church communities. ${ }^{19}$ The bishop explained to Catholics that all worshippers (clergy and laity) make up the living Church and constitute a system of communicating vessels. That is why each one should do their bit to make a positive contribution to the religious community which they are a part of. ${ }^{20}$

In practice, Tokarczuk wanted to use the potential of all Catholics exhibiting good will and the desire to cooperate in order to develop the Diocese of Przemyśl within the religious and social scope. The bishop was convinced that there is a "vast good will capital within people" and if it is skilfully awakened then "really great things become possible." 21 The bishop's openness to the needs of laypeople as well as the trust and kindness with which he treated them were sometimes criticised by members of the clergy who thought that at times the bishop is more willing to listen to lay people than priests. ${ }^{22}$

The diocesan frequently visited religious communities in order to strengthen them, to make sure their spirits were high, to help in overcoming the fear of the totalitarian authorities. During public appearances he persuaded Catholics to

\footnotetext{
${ }^{16}$ TOKARCZUK, "Śladami Vaticanum II," 4.

17 ToKarczuK, "O świeckich w Kościele w przeddzień synodu," 4.

${ }^{18}$ P. SZTOMPKA, Zaufanie. Fundament społeczeństwa (Kraków: Wydawnictwo Znak, 2007), 69-70; FUKUYAMA, Zaufanie, 38.

${ }^{19}$ I. TOKARCZuK, "Kościół w dwadzieścia lat po soborze," in Homilie i konferencje religijne. XXIX Dni Modlitw Kultury Chrześcijańskiej „Odrodzenie” 1985, vol. 4 (Warsaw: Kuria Metropolitarna Warszawska Wydział Duszpasterstwa, 1986), 22.

${ }^{20}$ I. TOKARCZUK, "Problematyka pastoralna w encyklice 'Redemptor hominis,"” Znak 31, no. 306 (1979), 1222.

${ }^{21}$ I. TOKARCZUK, "Nie pracuję sam, mam w zapleczu całą ofiarną diecezję..." Rozmowa z księdzem biskupem [...]. Rozmawiał M. Brat, Informator Duszpasterski "Serafik” 2, no. 6 (1989), 13.

${ }^{22}$ A. KustrA, "O apb. Ignacym bez zachwytu, a z wielkim uznaniem," in "Non omnis moriar." Abp Ignacy Tokarczuk we wspomnieniach, ed. M. Krzysztofiński (Rzeszów-Lwów: Instytut Pamięci Narodowej Komisja Ścigania Zbrodni przeciwko Narodowi Polskiemu Oddział w Rzeszowie, Uniwersytet Rzeszowski, Wydawnictwo bł. Jakuba Strzemię Archidiecezji Lwowskiej Obrządku Łacińskiego, 2016), 416-21.
} 
remain true to religious and patriotic values, to follow moral standards and to stand shoulder to shoulder in the defence of truth. Crowds of worshippers attended his passionate sermons to hear the words of truth and reassurance in a communist regime known for its use of deceitful propaganda. After listening to the bishop, worshippers returned to their homes spiritually stronger and convinced that suffering for truth and faith is justified. ${ }^{23}$

Not only did the group cooperation strategy implemented by Tokarczuk make it possible to effectively oppose the scattering of church communities and an atomisation of the society, but it also established a feeling of social solidarity and contributed to a more effective achievement of shared goals. ${ }^{24}$ Strengthening citizens' ability to sacrifice individual good for social good taught cooperation, reinforced trust and sense of solidarity, and influenced local communities' quality of life. Social capital based on community values and moral norms had an impact on building positive interpersonal relations. ${ }^{25}$ Integrating the society by strengthening interpersonal ties, creating informal groups, public and joint professions of faith, intimate interactions based on mutual trust and opposing the communist regime together unified the Podkarpackie community and contributed to the establishment of a farmers" "Solidarity." 26 Tokarczuk supported the postulates of farmers, in his opinion justified, who wanted to establish a trade union to protect the workers' rights and interests. ${ }^{27} \mathrm{He}$ met and advised representatives of the rural opposition. ${ }^{28} \mathrm{He}$ contributed to the signing of the Rzeszów-Ustrzyki Dolne Agreement between the communist authorities and the striking members of farmers' solidarity movements. Signing of the agreement paved the way for the establishment and official registration of

\footnotetext{
${ }^{23}$ T. BŁaszKIEWICZ, "Przedmowa," in I. ToKARCZuK, Kazania pasterskie 1966-1992 (Przemyśl: Wydawnictwo Archidiecezji Przemyskiej, 1992), 5.

${ }^{24}$ T. BŁaszKIEwicz, "Przedmowa," 5; K. Ryczan, "Laudacja Jego Ekscelencji Księdza Arcybiskupa Ignacego Tokarczuka w dniu uroczystości odnowienia doktoratu na Katolickim Uniwersytecie Lubelskim Jana Pawła II," in Odnowienie doktoratu arcybiskupa Ignacego Tokarczuka, ed. I. Pachcińska (Lublin: Wydawnictwo KUL, 2006), 20-1.

${ }^{25}$ M. ADAMCZYK, "Kapitał społeczny szansą na budowanie partnerskich relacji we wspólnotach lokalnych," in Pomoc jako zachowanie prospoteczne, ed. T. Zbyrad, and B. Krempa (Lublin: Wydawnictwo KUL, 2012), 493-500.

${ }^{26}$ BŁaszKiewicz, "Przedmowa," 5.

${ }^{27}$ S. ZŁONKIEWICZ, "Świeccy w Kościele diecezji przemyskiej," in Księga jubileuszowa 25 lat pasterskiego postugiwania ks. biskupa Ignacego Tokarczuka, ed. J.F. Adamski, and M. Rudnicka (Rzeszów-Stalowa Wola: Biblioteczka Przemyska, 1991), 209.

${ }^{28}$ Tajne dokumenty Państwo-Kościót 1980-1989 (Londyn-Warszawa: Aneks Publishers \& Polityka, 1993), 248.
} 
the Independent Self-governing Trade Union of Individual Farmers [NSZZ RI] "Solidarity." 29

When NSZZ "Solidarity" was banned during martial law in Poland, Tokarczuk staunchly defended it arguing that lifting the ban on the trade union and the release of jailed activists is in the interest of the Polish society. ${ }^{30}$ The communist authorities reacted to the bishop's public deliveries, wherein he defended workers and their rights to associate in independent trade unions. The hierarch was accused of undermining dialogue between the ruling party and the Church and of engaging in activities detrimental to the interests of a socialist state. ${ }^{31}$ The communists ascertained that the episcopate was using Przemyśl as a spearhead in its fight against the socialist regime. They even intended to bring the bishop before a court. ${ }^{32}$

Even though Tokarczuk was often attacked by the communist apparatus, he did not give up his social and religious activities. He made intensive efforts to strengthen the bonds between residents of villages and towns. He called on Catholics to draw upon religious principles, solidarity and brotherly love and-via municipal parishes-to supply agricultural produce to workers' families suffering severe consequences of the economic crisis. He referred to the social solidarity principle to justify the faithful helping one another, particularly when in danger. ${ }^{33}$ The bishop encouraged the faithful to maintain a family atmosphere in church communities so that no one was left without the support of fellow Catholics. Social love should constitute the basis for mutual relations and bonds. ${ }^{34}$

Tokarczuk acted as a spiritual leader in a dangerous situation full of uncertainty. He was able to convince the faithful that solidarity with the society and responsibility for its fate were more important than loyalty or obedience to the regime. Remaining faithful to the basic principles and universal standards which

${ }^{29}$ Ministry of InTERIOR. DePARTMENT IV, Almanach biskupów Kościoła katolickiego w Polsce (31 March 1988), (Ug-0818/88, Secret materials 033), typed manuscript at Archibishop Ignacy Tokarczuk's Private Archive, 189-90; J. SzKUTNIK, "Komitet Samoobrony Chłopskiej Ziemi Rzeszowskiej 1978-1980," Studia Rzeszowskie, no 2 (1995), 138.

30 "A stenographic record of the sermon delivered by Bishop Ignacy Tokarczuk, Jasna Góra, 5 September 1982," Zagadnienia i Materiaty (Central Committee of the Polish United Workers' Party [KC PZPR] Ideology Department Publication for party members), no. 37 (1982), 45-6.

31 "Dialog i jego przeciwienstwo," Zagadnienia i Materiaty (Central Committee of the Polish United Workers' Party [KC PZPR] Ideology Department Publication for party members), no. 37 (1982), 29.

${ }^{32}$ P. RaINA, Rozmowy z władzami PRL. Arcybiskup Dąbrowski w stużbie Kościoła i Narodu, vol. 1: 1970-1981 (Warsaw: Wydawnictwo Książka Polska, 1995), 351.

33 "A stenographic record of the sermon delivered by Bishop Ignacy Tokarczuk," 42.

34 A. Garbarz, Działalność duszpastersko-spoteczna arcybiskupa Ignacego Tokarczuka (Rzeszów: s.n., 2006), 267. 
social life should be based upon was the moral incentive for becoming engaged in efforts for the common good. In his deliveries, the Bishop of Przemyśl referred to human dignity and the basic rights notoriously ignored by the totalitarian system. He emphasised the significance of the right to express one's own opinions and in particularly the freedom to religious practice. He called upon the faithful to stay united and show solidarity, which were a necessary condition to oppose the repressive religious policies of the communist authorities.

\section{STRENGTHENING INTERPERSONAL TIES}

A practical and the most spectacular manifestation of religious social capital in the Diocese of Przemyśl was the growth of the sacral buildings' network and a transformation of parish structures. Tokarczuk appreciated the role played by the connection between Catholics and their own parish community in the religious social capital building process. And that is why he was trying to strengthen the bonds between the faithful and local religious communities. His underlaying assumption, based on missionary activities and sociological research, was that the bigger the parish, the relatively less active the faithful and the weaker the attachment to the parish. He observed a similar rule when it came to the correlation between the size of a parish and the level of religious practices. ${ }^{35}$ In the bishop's opinion a parish cannot be too large as that precludes a family spirit, a community spirit and sufficient care will not be extended to all the faithful. ${ }^{36} \mathrm{He}$ thus decided to improve the functioning of parish structures by splitting huge parishes, establishing new pastoral units and by building religious cult sites within them. ${ }^{37}$

In the process of increasing the number of Diocese of Przemyśl parishes and churches, Tokarczuk predominantly relied on the maturity and responsibility of lay Catholics. Bottom-up, often spontaneous initiatives by local communities

\footnotetext{
${ }^{35}$ I. TOKARCZUK, “Diecezja i parafia dla Kościoła przyszłości,” Niedziela 28, no. 17 (1985), 7; W. JEDYNAK, Apostolstwo ludzi świeckich w Kościele i świecie w ujęciu biskupa Ignacego Tokarczuka (1965-1993) (Łańcut: s.n., 1998), 80-1. See: W. SADŁoN, "Bardziej ubogo, ale przyzwoiciej," 192-4.

${ }^{36}$ I. TOKARCZUK, "List pasterski na 600-lecie diecezji przemyskiej," Kronika Diecezji Przemyskiej 62, no. 4 (1976), 83.

${ }^{37}$ A. Ротоскі, "Posoborowa organizacja Kościoła lokalnego," in Ksiega jubileuszowa 25 lat pasterskiego postannictwa ks. biskupa Ignacego Tokarczuka, ed. J.F. Adamski, and M. Rudnicka (Rzeszów-Stalowa Wola: Biblioteczka Przemyska, 1991), 63-6.
} 
supported and moderated by the bishop were an excellent opportunity to generate religious social capital. ${ }^{38}$

According to Tokarczuk, the primary objective of establishing religious cult centres was to increase the levels of Catholics' religious engagement by providing an opportunity for shared prayed in churches, uniting the local religious community. ${ }^{39}$ Strongly integrated religious communities are distinguished by a high level of social capital. ${ }^{40}$ The faithful congregating by an altar in a temple did not only bring people closer to God, but also to one another, creating a single, thoroughly integrated community (a parish family). However, before the faithful could congregate in shared prayers, they first had to build a church. In most cases this proved highly challenging under the authoritarian system of the Polish People's Republic. ${ }^{41}$

Tokarczuk drafted and consistently followed a strategy for establishing parishes and building churches in a totalitarian state. Its aim was to facilitate a transformation of the Diocese of Przemyśl by adapting it to the needs and expectation of the faithful. Furthermore it was to strengthen social bonds and integrate the faithful by converting parish congregations into local communities. ${ }^{42}$

The bishop decided that the size of a municipal parish (understood as the number of faithful) in a city cannot exceed 10 thousand, whereas in rural areas a parish church cannot be more than $4 \mathrm{~km}$ away. ${ }^{43}$ The plan assumed for these undertakings to be pursued regardless of administrative decisions made by government bodies. When it came to establishing parishes Tokarczuk did not ask officials for their permission at all, as he considered it to be the Church's

${ }^{38}$ H. SZAREYKo, Nielegalne budownictwo sakralne jako fenomen religijno-spoteczny. Studium na przykładzie diecezji przemyskiej, $2^{\text {nd }}$ ed., updated and amended (Wrocław: Bonus Liber, 2008), 83-4.

${ }^{39}$ A. Ротоскі, Diecezja przemyska w swe 600-lecie, vol. 2 (Przemyśl: s.n., 1983), 514-5; '"Ze Zbaraża do Przemyśla," A. Kruczek interviews HE fr. archb. Ignacy Tokarczuk, Nasz Dziennik (June 23-24, 2012), access October 2, 2018, https://naszdziennik.pl/mysl/2034,ze-zbaraza-do-przemysla.html.

${ }^{40}$ M. ADAMCZYK, "Praktyki religijne jako jeden z czynników tworzenia zasobów kapitału społecznego w Polsce," in Religijne wymiary życia społecznego, ed. H. Mielicka-Pawłowska (Kielce: Wyd. Panzet, 2013), 238.

${ }^{41}$ I. ToKARCZUK, "Bóg nam zaufał, bądźmy odpowiedzialni." Interview with His Excellency the Bishop [...] Przemyśl diocesan, Interviewers: A. Bernat and I. Saryusz-Wolska, Przeglad Katolicki 75, no. 16-17 (1987), 8-9, Interviews conducted by T. Fredro-Boniecki (Paris: Editiones du Dialogue Societe D'Editions Internationales, 1994), 78-9.

${ }^{42}$ P. CHMiElowiec, "Działania operacyjne Służby Bezpieczeństwa wobec biskupa Ignacego Tokarczuka i kurii biskupiej w Przemyślu w latach 1966-1989," in Aparat bezpieczeństwa wobec kurii biskupich w Polsce, ed. A. Dziurok (Warsaw: Institute for National Remembrance the Commission for the Prosecution of Crimes Against the Polish Nation, 2009), 307-8.

${ }^{43}$ I. ToKARCZUK, Moc $i$ wytrwatośćc, Selected and ed. T. Fijałkowski, and J. Illg, $2^{\text {nd }}$ ed. (Kraków: Znak, 1987), 5. 
internal matter. Whereas the religious communities themselves applied to the authorities for permits to build churches. In most cases these were rejected, and as a result construction of sacral buildings began without official permits, running the risk of court cases and steep fines. ${ }^{44}$ In 1975 the Polish People's Republic's national administration bodies only approved $6 \%$ of all the church building permit applications submitted in Poland. ${ }^{45}$

Mutual trust and cooperation were a significant element of illegal church building. The bishop together with priests and the faithful would agree in secrecy upon the details pertaining to the way a parish was to be organised or a church built. The point was to prevent details of the planned site for a new religious cult venue from seeping through to undercover security services collaborators. If the communist authorities became aware of the intentions prematurely, then the construction of a church would be prevented and further works foiled by the security services. Success of an investment was based on mutual trust. Cooperation between community members relied on honest conduct governed by shared moral standards. Once preparations for construction works were sufficiently advanced, actual works would begin and such information would be announced publicly. ${ }^{46}$

An initiative which initially only a few trusted individuals were privy to, began growing, its impact expanding to other members of parish communities. More and more people bound by responsibility, solidarity, trust, reciprocity and cooperation standards became involved. Despite objections of the authorities, the idea of the sacral buildings in the Diocese of Przemyśl gradually radiated outwards, breaching the boundaries of local parish communities and engrossed the entire diocese. It even served as inspiration for other dioceses.

For the faithful erecting temples, Tokarczuk was a spiritual leader and a moral authority. The bishop wasn't only interested in progress within the scope of sacral buildings, but also supported local communities' undertakings in various ways. ${ }^{47}$ For him, each and every built church constituted another victory in the struggle against communist authorities. One of the priests said that the bishop, like a chief, would develop a strategy, oversee its execution and direct the campaign itself whilst "encouraging priests and the faithful to become involved, would send them to the front lines." $" 48$ The strategy implemented by the diocesan

${ }^{44}$ RAINA, Rozmowy z wtadzami PRL, 122.

${ }^{45}$ A. MICEWSKI, Kardynat Wyszyński, prymas i mąż stanu (Paris: Editions du Dialogue, 1982), 351.

${ }^{46}$ BEŁCH, Strategie duszpasterskie arcybiskupa Ignacego Tokarczuka, 221-2.

${ }^{47}$ A. Garbarz, "Wspomnienie," in Pożegnanie Niezłomnego Pasterza Arcybiskupa Ignacego Tokarczuka (Przemyśl: Wydawnictwo i Drukarnia Diecezji Rzeszowskiej, 2013), 43.

${ }^{48}$ Kustra, “O abp. Ignacym bez zachwytu, a z wielkim uznaniem,” 417. 
was a long term programme, with precisely defined goals and means for their achievement. $^{49}$

The illegal sacral buildings construction process initiated by Tokarczuk was strongly criticised by the communist authorities, which demanded Polish episcopate leaders to stem the civil disobedience acts initiated by the Bishop of Przemyśl, ostensibly undermining the authority of the ruling party. ${ }^{50}$ Once it was clear that these efforts are ineffective, the communists approached the Vatican in order to convince the topmost Church authorities to influence Tokarczuk into obedience to the state or to remove him from the post of diocesan for continually breaching national regulations. However, these actions were ineffective as the decision-makers in the Vatican refused to be drawn into the cunning ploys of the communists. With the staunch support of Pope Paul VI, Primate Cardinal Stefan Wyszyński and the Polish episcopate, Tokarczuk remained steadfast. ${ }^{51}$

Tokarczuk was in favour of decentralising pastoral work. In his opinion, pastoral work managed centrally and from above will be ineffective when it comes to "dealing with certain problems." ${ }^{, 52}$ In sharing responsibility with his colleagues, he would say that he was relying on their professionalism and skills: "The situation in the current pastoral work is akin to that at the front lines. In the past, a commander would thoroughly specify all the tasks assigned to soldiers and would demand obedience and loyalty in the execution of orders. Today these tasks ore only roughly outlined and each soldier has to think for themselves and adapt the general directives to the given situation because a commander is unable to be familiar with nor foresee every situation." 53

For the Podkarpackie residents, the Bishop of Przemyśl was an undisputed leader. The hierarch did not hide behind others when churches were built illegally in the diocese but publicly supported the investments, took a personal interest in their progress and also stood up to the concentrated attacks by the communist authorities. ${ }^{54}$ Without doubt, people directly involved in illegal church construction faced the most severe repressions. These people were tried and sentenced to

\footnotetext{
${ }^{49} \mathrm{BE \ell CH}$, "Strategie duszpasterskie arcybiskupa Ignacego Tokarczuka," 218.

${ }^{50}$ A. DudeK, and R. GRYZ, Komuniści i Kościót w Polsce (1945-1989) (Kraków: Wydawnictwo Znak, 2006), 287, 313-5.

${ }^{51}$ DudeK, and Gryz, Komuniści i Kościót w Polsce, 296.

52 I. TOKARCZUK, Ustawodawstwo biskupa przemyskiego Ignacego Tokarczuka $w$ latach 1966-1993, comp. Z. Głowacki (Przemyśl 1992), 52 (Typed Manuscript).

${ }^{53}$ I. TOKARCZUK, "Kochatem tych ludzi catym sercem i oddaniem." Wspomnienia z lat 1918-1976, comp. J. Wołczański (Lwów-Kraków: Wydawnictwo bł. Jakuba Strzemię Archidiecezji Lwowskiej, 2014), 175.

${ }^{54}$ Tajne dokumenty, 471; S. BoBER, "Persona non grata." Biskup Ignacy Tokarczuk $i$ wtadze PRL, vol. 1 (Lublin: Wydawnictwo-Drukarnia Liber Duo s.c., 2005), 219.
} 
prison or hefty fines. For those convicted, group solidarity was paramount, as their fellow worshippers did not leave them without help or support. Tokarczuk made it clear in public that no one convicted shall be abandoned or left to their own devices. To the contrary, the church community will pay the financial fines for them and help them to find a job. As it was commonplace for people involved in an illegal church building or those praying in illegally erected religious cult sites to be made redundant, expelled from universities etc. ${ }^{55}$

The trust shown towards fellow worshippers together with religious faith gave Catholics the feeling of solidarity and unity, reinforced the belief in mutual support and of being deeply set in the community of fellow worshippers. Mutual trust in interpersonal relations was not only limited to the circle of the closest people, but also included people who were little known or even strangers. Trust in the loved ones and trust in the human being in general were positively connected and built up binding and bridging capital. ${ }^{56}$ For believers the bonds with fellow worshippers were akin to those with their family members. They were convinced that they were part of the great Church family. Being part of a religious community stimulated their conviction that they were not left to their own devices, but that they can count on the help of other members of the church whenever required.$^{57}$ Praying together and participating in religious practices has had a positive impact on increasing the level of activity. ${ }^{58}$

The undertakings initiated by Tokarczuk showed that he activated local religious communities pointing to goals of a common good nature, which-through the use of local resources-were performed by the joint efforts of local Catholics. Execution of investments-an in particular building of churches under constant threat-increased cohesion of a group whose members acted together in order to build their temple. Almost all the works were performed economically within a society. The faithful would make financial donations and contribute labour-each within their own capacity_to the building process. Frequent meetings, sharing of experiences and ideas, joint acquisition of construction materials, common manual labour, and collectively overcoming obstacles seasoned people and brought

\footnotetext{
${ }^{55}$ M. WinowsKa, "Wstęp," in A. Boniecki Budowa kościołów w diecezji przemyskiej (Paris: Biblioteka Spotkań, b. r.), 10.

${ }^{56}$ See M. Freitag, and R. TraunmüLler, "Spheres of Trust: An Empirical Analysis of the Foundations of Particularised and Generalised Trust," European Journal of Political Research 48, no 6 (2009), 782-803.

${ }^{57}$ SZTOMPKA, Zaufanie, 290-1.

${ }^{58}$ ADAMCZYK, "Praktyki religijne," 253.
} 
them closer together. The mutual trust would increase on the basis of honest and cooperative conduct governed by shared standards and values. ${ }^{59}$

The outcome of collective cooperation based on mutual trust, solidarity and shared values and standards was impressive across the entire diocese. During the period when the Diocese of Przemyśl was under Tokarczuk's leadership, approximately 400 parish and filial churches were built and almost the same number of religious and parish buildings. 225 parishes were created. Erection of a sacral building by the local community was a condition for their establishment. Cooperation amongst the bishop, priests and lay believers facilitated a restructuring of parishes at a scale unprecedented thus far. ${ }^{60}$ Cooperation amongst local communities moderated by Tokarczuk contributed to integration and solidarity of worshippers engaged in a shared objective's performance. Additionally, it served as an example of bottom-up initiatives and joint actions. ${ }^{61}$ Interest in parish community matters and the feeling of responsibility for the common good increased amongst Catholics. Interpersonal relations flourished, new relationships emerged. Self-sacrifice and devotion was on the rise. Only intensive and joint efforts made it possible for an undertaking to be successfully completed. ${ }^{62}$

The stimulated activity expressed itself in the dynamic growth of church groups and associations. Farmers', workers' and intelligentsia status-related and professional missions sprung up and operated in many parishes. The living Church grew together with the growth of sacral buildings. ${ }^{63}$ Levels of religious and moral lives increased. Mass attendance was also on the rise, sacraments were celebrated more frequently. A decrease is deviative behaviours was recorded. ${ }^{64}$

${ }^{59}$ I. TOKARCZUK, Kazania pasterskie 1966-1992 (Przemyśl: Wydawnictwo Archidiecezji Przemyskiej, 1992), 105.

${ }^{60}$ M. RUDNICKA, "Budownictwo sakralne misją trudnych czasów," in Księga jubileuszowa 25 lat pasterskiego postannictwa ks. biskupa Ignacego Tokarczuka, eds. J. F. Adamski, and M. Rudnicka (Rzeszów-Stalowa Wola: Biblioteczka Przemyska, 1991), 91.

${ }^{61}$ E. FirLIT, Parafia rzymskokatolicka w Polsce w okresie transformacji systemowej (studium socjologiczne) (Warsaw: Elipsa, 1998), 118.

62 BЕŁCH, "Strategie duszpasterskie arcybiskupa Ignacego Tokarczuka," 226-7; K. BEŁCH, "Wprowadzenie," in Nowe kościoty w diecezji przemyskiej w jej dawnych granicach powstałe w latach 1966-1992, eds. J. Bar, and A. Szal (Przemyśl: Wydawnictwo Archidiecezji Przemyskiej, 1993), 13.

${ }^{63}$ J. Draus, "Katolicy świeccy w diecezji przemyskiej," Niedziela, no. 44-45 (1988), 14; W. JEDYNAK, "Znaczenie zorganizowanych grup laikatu (chłopów, robotników i inteligencji) w życiu Kościoła lokalnego według bpa Ignacego Tokarczuka,” Studia Sandomierskie 13, f. 2 (2006), 63-71.

${ }^{64} \mathrm{~K}$. BEŁCH, Dynamika przemian zachowań religijno-moralnych $w$ warunkach tworzenia nowych parafii. Studium socjologiczne na przyktadzie diecezji przemyskiej w latach 1966-1985 (Przemyśl: Wydawnictwo Archidiecezji Przemyskiej, 1999), 69-112, 115-36; ВЕєCH, "Wprowadzenie," 14-5. 
Bishop Tokarczuk is an example of a leader who was able to skilfully build social capital on the basis of religious resources. He had bishops, priests and lay Catholics at his disposal devoted and committed to the common good, who collectively pursued common goals. Through people like Tokarczuk, Poland became the change leader in the Eastern Bloc, heading towards democratisation of public life and the creation of civil society.

The Bishop of Przemyśl showed understanding for the circumstances of his followers and had an uncanny ability to find solutions in difficult situations. He was known for helping the needy and supporting those facing repressions. The appreciation, trust and social support he enjoyed were founded on his openness and kind-heartedness. During the communist era Catholics saw him as the spiritual leader of the Diocese of Przemyśl. Frequently going out to meet the faithful during various occasions or celebrations, receiving parish representatives in the diocesan curia or visiting parishes meant that he was in constant touch with the local parish communities and aware of the needs and expectations of ordinary people. He was able to make the right decisions based on his extended knowledge about the functioning of religious communities. He initiated valuable undertakings and oversaw their execution, taking into account local conditions. He moderated the operations of informal, bottom-up groups. He skilfully released social capital required for collective and effective cooperation for the common good.

The social and religious initiatives undertaken by Tokarczuk made it possible to complete common objectives and goals, integrate local parish communities, strengthened social bonds, built interpersonal relations, increased the feeling of responsibility and motivated for more profound engagement in local religious community matters, taught self-organisation and cooperation, deepened mutual trust, released creativity and entrepreneurship, shaped the local identity and also created opportunities for future cooperation. Under a totalitarian regime of a socialist state, the bishop laid lasting foundations for the building of a civil society.

Tokarczuk was able to make use of the potential of small groups and release the social capital present therein in the form of added value resulting from the establishment of powerful bonds in order to complete a common goal. Focused and concentrated actions by group members transformed into their common good generated as a result of cooperation and positive interpersonal relations. Thus, religious social capital constituted the outcome of pursuing the bishop's, priests' and lay people's common goals, which were converted into joint benefits as a result the relations between individuals. 


\section{BIBLIOGRAPHY}

ADAMCZYK, Monika. "Kapitał społeczny szansą na budowanie partnerskich relacji we wspólnotach lokalnych.” In Pomoc jako zachowanie prospoteczne, edited by Teresa Zbyrad, and Bogdan Krempa, 489-500. Lublin: Wydawnictwo KUL, 2012.

ADAMCZYK, Monika. "Praktyki religijne jako jeden z czynników tworzenia zasobów kapitału społecznego w Polsce." In Religijne wymiary życia społecznego, edited by Halina Mielicka-Pawłowska, 237-54. Kielce: Wyd. Panzet, 2013.

ADAMCZYK, Monika. Wprowadzenia do teorii kapitatu spotecznego. Lublin: Wydawnictwo KUL, 2013.

AleXANDER, Marcus. "Determinants of Social Capital: New Evidence on Religion, Diversity and Structural Change.” British Journal of Political Science 37, no 2 (2007): 368-77.

"A stenographic record of the sermon delivered by Bishop Ignacy Tokarczuk, Jasna Góra, 5 September 1982." Zagadnienia i Materiaty (Central Committee of the Polish United Workers' Party [KC PZPR] Ideology Department Publication for party members), no 37 (1982): 42-7.

BEŁCH, Kazimierz. Dynamika przemian zachowań religijno-moralnych $w$ warunkach tworzenia nowych parafii. Studium socjologiczne na przykładzie diecezji przemyskiej w latach 1966-1985. Przemyśl: Wydawnictwo Archidiecezji Przemyskiej, 1999.

BеєCH, Kazimierz. "Strategie duszpasterskie arcybiskupa Ignacego Tokarczuka.” In Arcybiskup Ignacy Tokarczuk w oczach społeczeństwa, edited by Jan Zimny, 217-28. Sandomierz: Wydawnictwo Diecezjalne, 2003.

BeŁch, Kazimierz. "Wprowadzenie.” In BAR, Józef, and Adam SzAL. Nowe kościoty w diecezji przemyskiej w jej dawnych granicach powstate w latach 1966-1992, 3-16. Przemyśl: Wydawnictwo Archidiecezji Przemyskiej, 1993.

BŁAszKiewicz, Tadeusz. "Przedmowa." In ToKarczuk, Ignacy. Kazania pasterskie 1966-1992, 5-7. Przemyśl: Wydawnictwo Archidiecezji Przemyskiej, 1992.

Bober, Sabina. "Persona non grata." Biskup Ignacy Tokarczuk i wtadze PRL, vol. 1. Lublin: Drukarnia Liber Duo s.c., 2005.

ChMielowiec, Piotr. "Działania operacyjne Służby Bezpieczeństwa wobec biskupa Ignacego Tokarczuka i kurii biskupiej w Przemyślu w latach 1966-1989." In Aparat bezpieczeństwa wobec kurii biskupich w Polsce, edited by Adam Dziurok, 282-316. Warsaw: Instytut Pamięci Narodowej. Komisja Ścigania Zbrodni przeciwko Narodowi Polskiemu, 2009.

"Dialog i jego przeciwieństwo." Zagadnienia $i$ Materiaty (Central Committee of the Polish United Workers' Party [KC PZPR] Ideology Department Publication for party members), no 37 (1982): 23-9.

Draus, Jan. "Katolicy świeccy w diecezji przemyskiej.” Niedziela, no $44-45$ (1988): 14.

DudeK, Antoni, and Ryszard. GRYZ. Komuniści i Kościót w Polsce (1945-1989). Kraków: Wydawnictwo Znak, 2006.

FIRLIT, Elżbieta. Parafia rzymskokatolicka w Polsce w okresie transformacji systemowej (studium socjologiczne). Warsaw: Elipsa, 1998.

FrankowsKi, Edward. “Homilia.” In Pożegnanie „Niezłomnego Pasterza” Arcybiskupa Ignacego Tokarczuka, edited by Jerzy Łoboz, 10-6. Przemyśl: Wydawnictwo i Drukarnia Diecezji Rzeszowskiej, 2013. 
FreitAG, Marcus, and Richard, TraunMüLLER. "Spheres of trust: An empirical analysis of the foundations of particularised and generalised trust." European Journal of Political Research 48, no 6 (2009): 782-803.

FukuYama, Francis. Zaufanie. Kapitat spoteczny a droga do dobrobytu. Translated by Anna and Leszek Śliwa. Warsaw-Wrocław: Wydawnictwo Naukowe PWN, 1997.

Garbarz, Andrzej. Dziatalność duszpastersko-spoteczna arcybiskupa Ignacego Tokarczuka. Rzeszów: [s. n.], 2006.

GarbarZ, Andrzej. “Wspomnienie.” In Pożegnanie „Niezłomnego Pasterza” Arcybiskupa Ignacego Tokarczuka, edited by Jerzy Łoboz, 42-3. Przemyśl: Wydawnictwo i Drukarnia Diecezji Rzeszowskiej, 2013.

JeDYNAK, Witold. Apostolstwo ludzi świeckich w Kościele $i$ świecie w ujęciu biskupa Ignacego Tokarczuka (1965-1993). Łańcut: [s. n.], 1998.

JEDYNAK, Witold. "Znaczenie zorganizowanych grup laikatu (chłopów, robotników i inteligencji) w życiu Kościoła lokalnego według bpa Ignacego Tokarczuka.” Studia Sandomierskie 13, f. 2 (2006): 61-72.

KustRA, A. “O apb. Ignacym bez zachwytu, a z wielkim uznaniem.” In "Non omnis moriar.” Abp Ignacy Tokarczuk we wspomnieniach, edited by Mariusz Krzysztofiński, 414-26. Rzeszów-Lwów: Instytut Pamięci Narodowej Komisja Ścigania Zbrodni przeciwko Narodowi Polskiemu Oddział w Rzeszowie, Uniwersytet Rzeszowski, Wydawnictwo bł. Jakuba Strzemię Archidiecezji Lwowskiej Obrządku Łacińskiego, 2016.

MicewsKi, Andrzej. Kardynat Wyszyński, prymas i mąż stanu. Paris: Editions du Dialogue, 1982.

Ministry of InTERIOR. DePARTAMENT IV. Almanach biskupów Kościoła katolickiego w Polsce (31 march 1988), (Ug-0818/88, Secret materials 033). Typescript in Private Archive Archbishop Ignacy Tokarczuk.

Ротоскі, Andrzej. Diecezja przemyska w swe 600-lecie, vol. 2. Przemyśl: [s. n.], 1983.

Pотоскі, Andrzej. "Posoborowa organizacja Kościoła lokalnego.” In Ksiega jubileuszowa 25 lat pasterskiego postannictwa ks. biskupa Ignacego Tokarczuka, edited by Jerzy F. Adamski, and Małgorzata Rudnicka, 61-84. Rzeszów-Stalowa Wola: Biblioteczka Przemyska, 1991.

Putnam, Robert D. Samotna gra w kręgle. Upadek i odrodzenie wspólnot lokalnych w Stanach Zjednoczonych. Warsaw: Wydawnictwa Akademickie i Profesjonalne, 2008.

RaINA, Peter. Rozmowy z władzami PRL. Arcybiskup Dabrowski w stużbie Kościoła i Narodu. Vol. 1: 1970-1981. Warsaw: Wydawnictwo Książka Polska, 1995.

RUDNICKA, Małgorzata. "Budownictwo sakralne misją trudnych czasów.” In Księga jubileuszowa 25 lat pasterskiego postannictwa ks. biskupa Ignacego Tokarczuka, edited by Jerzy F. Adamski, and Małgorzata Rudnicka, 85-97. Rzeszów-Stalowa Wola: Biblioteczka Przemyska, 1991.

RyCZAN, Kazimierz. "Laudacja Jego Ekscelencji Księdza Arcybiskupa Ignacego Tokarczuka w dniu uroczystości odnowienia doktoratu na Katolickim Uniwersytecie Lubelskim Jana Pawła II.” In Odnowienie doktoratu arcybiskupa Ignacego Tokarczuka, edited by Iwona Pachcińska, 15-21. Lublin: Wydawnictwo KUL, 2006.

SADŁOŃ, Wojciech. “'Bardziej ubogo, ale przyzwoiciej.' Oddziaływanie religijnego kapitału społecznego w Polsce.” Zeszyty Naukowe KUL 57, no 1 (2014): 11-29.

SADŁoŃ, Wojciech. Religijny kapitat spoteczny. Kapitat spoteczny a Kościót katolicki w spotecznościach lokalnych w Polsce. Wydawnictwo Bezkresy Wiedzy, 2014. Accessed November, 11, 2018. https://www.researchgate.net/publication/303523181_Religijny_kapital_spoleczny. 
SIEROCIŃSKA, Katarzyna. "Kapitał społeczny. Definiowanie, pomiar i typy.” Studia Ekonomiczne, no 1 (2011): 69-86.

SOBÓR WATYKAŃSKI II, "Dekret o apostolstwie świeckich Apostolicam actuositatem." In Konstytucje, dekrety, deklaracje, $3^{\text {rd }}$ ed., 379-405. Poznań: Wydawnictwo Pallottinum, 1986.

SOBÓR WATYKAŃSKI II, "Konstytucja duszpasterska o Kościele w świecie współczesnym Gaudium et spes." In Konstytucje, dekrety, deklaracje, $3^{\text {rd }}$ ed., 537-620. Poznań: Wydawnictwo Pallottinum, 1986.

SZAREYKO, Henryk. Nielegalne budownictwo sakralne jako fenomen religijno-spoteczny. Studium na przyktadzie diecezji przemyskiej, $2^{\text {nd }}$ ed. updated and amended. Wrocław: Bonus Liber, 2008.

SzczureK, Tadeusz. "Konsekracja oraz ingres do bazyliki katedralnej w Przemyślu J.E. Ks. Biskupa Ignacego Tokarczuka.“ Kronika Diecezji Przemyskiej 52, f. 2 (1966): 40-8.

SzKuTNIK, Janusz. "Komitet Samoobrony Chłopskiej Ziemi Rzeszowskiej 1978-1980.” Studia Rzeszowskie, no 2 (1995): 135-43.

SzTOMPKA, Piotr. Kapitat społeczny. Teoria przestrzeni międzyludzkiej. Kraków: Wydawnictwo Znak, 2016.

SzTOMPKA, Piotr. Zaufanie. Fundament spoteczeństwa. Kraków: Wydawnictwo Znak, 2007.

ŚwIDA-ZIEMBA, Hanna. Cztowiek wewnętrznie zniewolony. Mechanizmy i konsekwencje minionej formacji - analiza psychospoteczna. Warsaw: Zakład Socjologii Moralności i Aksjologii Ogólnej, Instytut Stosowanych Nauk Społecznych, Uniwersytet Warszawski, 1997.

Tajne dokumenty Państwo-Kościót 1980-1989, Londyn-Warszawa: Aneks Publishers \& Polityka, 1993.

TARNIEWSKI, Marek [Karpiński J.]. Ewolucja czy rewolucja. Paryż: Instytut Literacki, 1975.

ToKARCzUK, Ignacy. "Bóg nam zaufał, bądźmy odpowiedzialni. Rozmowa z Jego Ekscelencją księdzem biskupem [...] ordynariuszem przemyskim." Rozmawiały Anna Bernat, and Iwona Saryusz-Wolska. Przegląd Katolicki 75, no 16-17 (1987): 8-9.

TOKARCZUK, Ignacy. “Cywilizacja miłości.” Nasza Rodzina, no 5 (1986): 24-31.

TOKARCZUK, Ignacy. "Diecezja i parafia dla Kościoła przyszłości.” Niedziela 28, no 17 (1985): 1, 7.

TOKARCZUK, Ignacy. "Integracyjna rola diecezji przemyskiej w Małopolsce po ostatniej wojnie." In Diligis me? Pasce, vol. 1, edited by Stanisław Czerwik, and Małgorzata Mierzwa, 766-80. Sandomierz: Wydawnictwo Diecezjalne, 1999.

ToKARCZuK, Ignacy. Kazania pasterskie 1966-1992. Przemyśl: Wydawnictwo Archidiecezji Przemyskiej, 1992.

TOKARCZUK, Ignacy. "Kochałem tych ludzi całym sercem i oddaniem.” Wspomnienia z lat 1918-1976, Comp. by Józef Wołczański. Lwów-Kraków: Wydawnictwo bł. Jakuba Strzemię Archidiecezji Lwowskiej, 2014.

TOKARCZuK, Ignacy. "Kościół w dwadzieścia lat po soborze.” In Homilie i konferencje religijne. XXIX Dni Modlitw Kultury Chrześcijańskiej „Odrodzenie” 1985, vol. 4, 15-32. Warszawa: Kuria Metropolitarna Warszawska Wydział Duszpasterstwa, 1986.

TOKARCZUK, Ignacy. "List pasterski na 600-lecie diecezji przemyskiej.” Kronika Diecezji Przemyskiej 62, no 4 (1976): 83-7.

TOKARCZUK, Ignacy. Moc i wytrwatość. Selected and edited by Tomasz Fijałkowski, and Jerzy Illg, 2rd ed. Kraków: Znak, 1987.

TOKARCZUK, Ignacy. “'Nie pracuję sam, mam w zapleczu całą ofiarną diecezję...’ Rozmowa z księdzem biskupem [...]. Rozmawiał Michał Brat.” Informator Duszpasterski “Serafik” 2, no 6 (1989): 12-5. 
TOKARCZUK, Ignacy. "O świeckich w Kościele w przeddzień synodu. Wywiad z biskupem przemyskim [...]. Rozmawiał Franciszek Szpor.” Gość Niedzielny 64, no 39 (1987): 1, 4-5.

TOKARCZUK, Ignacy. "Problematyka pastoralna w encyklice 'Redemptor hominis.”' Znak 31, no 306 (1979): 1219-36.

TOKARCZuK, Ignacy. "Śladami Vaticanum II. Rozmowa z ojcem synodalnym [...]. Rozmawiała siostra J. Makowicz." Niedziela 30, no 47 (1987): 1, 4.

TOKARCZUK, Ignacy. Ustawodawstwo biskupa przemyskiego Ignacego Tokarczuka $w$ latach 1966-1993. Comp. by Zbigniew Głowacki. Przemyśl 1992 Typed Manuscript.

TOKARCZUK, Ignacy. W starciu z totalitaryzmem. Rozmowy przeprowadzit Tadeusz Fredro-Boniecki. Paris: Editiones du Dialogue Societe D'Editions Internationales, 1994.

TOKARCZuK, Ignacy. Z przemyskiej “twierdzy”. Part 1. Comp. by Lucyna Żbikowska. Marki: Michalineum, 1999.

Weron, Eugeniusz. Apostolstwo katolickie. Zarys teologii apostolstwa. Poznań: Pallottinum, 1987.

Weron, Eugeniusz. Budzenie olbrzyma. Laikat - duchowość - apostolstwo. Akcja Katolicka. Poznań: Pallottinum, 1995.

Winowska, Maria. “Wstęp.” In BonIECKI, Adam. Budowa kościołów w diecezji przemyskiej, 9-12. Paris: Biblioteka Spotkań, br.

“'Ze Zbaraża do Przemyśla.’ Ignacy Tokarczuk interviews Adam Kruczek.” Nasz Dziennik (June 23-24, 2012). Accessed October 2, 2018. https://naszdziennik.pl/mysl/2034,ze-zbaraza-do-prze mysla.html.

ZŁONKIEwICZ, Stanisław. "Świeccy w Kościele diecezji przemyskiej.” In Księga jubileuszowa 25 lat pasterskiego postugiwania ks. biskupa Ignacego Tokarczuka, edited by Jerzy F. Adamski, and Małgorzata Rudnicka, 207-20. Rzeszów-Stalowa Wola: Biblioteczka Przemyska, 1991

\section{THE LEADER'S ROLE IN BUILDING RELIGIOUS SOCIAL CAPITAL: A RELIGIOUS REGIONAL COMMUNITY LEADER IN POLAND}

\section{Summary}

This paper analyses the religious and social efforts of Bishop Ignacy Tokarczuk in order to identify his role in the process of generating religious social capital. The research was based on an analysis of available sources and in particular published texts on the Bishop's pastoral work. It demonstrates that during the difficult times of the communist era, the Bishop of Przemyśl was an unquestioned leader of local communities, who used religious resources to build religious social capital. Bishop Tokarczuk skilfully balanced Catholic bottom-up initiatives and activated local religious communities. His religious and social efforts prepared the ground for building a civil society. The results of Bishop's social and religious work, which priests and lay Catholics also became involved in were impressive.

Keywords: religious social capital; common good; trust; leader; religious local communities; cooperation; bp. Ignacy Tokarczuk. 


\section{ROLA LIDERA W BUDOWANIU RELIGIJNEGO KAPITAŁU SPOŁECZNEGO NA PRZYKŁADZIE LIDERA REGIONALNEJ SPOŁECZNOŚCI RELIGIJNEJ W POLSCE}

\section{Streszczenie}

Artykuł analizuje religijną i społeczną aktywność biskupa Ignacego Tokarczuka w celu wskazania jego roli w procesie wytwarzania religijnego kapitału społecznego. Badania zostały oparte na analizie dostępnych źródeł, w szczególności tekstów dotyczących pracy duszpasterskiej Tokarczuka. Badania wskazują, że w trudnym okresie epoki komunistycznej biskup przemyski był niekwestionowanym liderem lokalnej społeczności używającym środków religijnych do budowania religijnego kapitału społecznego. Biskup Tokarczuk zręcznie umacniał katolickie inicjatywy oddolne i aktywizował lokalne wspólnoty religijne. Jego religijne i społeczne wysiłki przygotowały podstawy do budowy społeczeństwa obywatelskiego. Rezultaty społecznej i religijnej pracy Biskupa, w którą były zaangażowane zarówno osoby duchowne, jak i świeckie, były imponujące.

Słowa kluczowe: religijny kapitał społeczny; dobro wspólne; zaufanie; przywódca; religijne wspólnoty lokalne; współpraca; bp Ignacy Tokarczuk. 